\title{
Impairment of the mitochondrial oxidative response to D-glucose in pancreatic islets from adult rats injected with streptozotocin during the neonatal period
}

\author{
M.-H. Giroix ${ }^{1}$, A. Sener ${ }^{2}$, D. Bailbe ${ }^{1}$, B. Portha ${ }^{1}$ and W. J. Malaisse ${ }^{2}$ \\ ${ }^{1}$ Laboratoire de Physiologie du Développement, Université de Paris, Paris, France, and \\ ${ }^{2}$ Laboratory of Experimental Medicine, Brussels Free University, Brussels, Belgium
}

\begin{abstract}
Summary. Pancreatic islets removed from adult rats injected with streptozotocin during the neonatal period display an impaired secretory response to D-glucose and, to a lesser extent, to L-leucine. Despite normal to elevated hexokinase and glucokinase activities in the islets of these glucose-intolerant animals and despite normal mitochondrial binding of the hexokinase isoenzymes, the metabolic response to a high concentration of D-glucose is severely affected, especially in terms of D-[6- $\left.{ }^{14} \mathrm{C}\right]$ glucose oxidation. Thus, the ratio in $\mathrm{D}-\left[6{ }^{-{ }^{14} \mathrm{C}}\right]$ glucose oxidation/D-[5- $\left.{ }^{3} \mathrm{H}\right] \mathrm{glucose}$ utilization is much less markedly increased in response to a rise in hexose concentration and, at a high concentration of D-glucose $(16.7 \mathrm{mmol} / \mathrm{l})$, less markedly decreased by the absence of $\mathrm{Ca}^{2+}$ and presence of cycloheximide in diabetic than control rats. This metabolic defect contrasts with (1) a close-to-normal or even increased capacity of the islets of diabetic rats to oxidize D- $\left[6-{ }^{-14} \mathrm{C}\right]$ glucose, $\left[2-{ }^{14} \mathrm{C}\right]$ pyruvate, $\mathrm{L}-\left[\mathrm{U}-{ }^{14} \mathrm{C}\right] \mathrm{glu}-$ tamine and $\mathrm{L}-\left[\mathrm{U}-{ }^{14} \mathrm{C}\right]$ leucine at low, non-insulinotropic, con-
\end{abstract}

centrations of these substrates; (2) a lesser impairment of the oxidation of $\mathrm{L}-\left[\mathrm{U}-{ }^{14} \mathrm{C}\right]$ leucine tested in high concentration $(20 \mathrm{mmol} / \mathrm{l})$, the effect of $\mathrm{Ca}^{2+}$ deprivation upon the latter variable being comparable in diabetic and control rats; (3) an unaltered transamination of either $\left[2-{ }^{-14} \mathrm{C}\right]$ pyruvate or L-[U${ }^{14} \mathrm{Clleucine}$; and (4) a modest perturbation of glycolysis. The most obvious alteration in glycolysis consists in a lesser increase of the glycolytic flux in response to a rise of D-glucose concentration in diabetic than control rats, this coinciding with an apparent decrease in affinity of glucokinase for the hexose. It is speculated that the preferential impairment of the metabolic and secretory response to D-glucose may be mainly attributable to an altered coupling between calcium accumulation and the stimulation of oxidative events in Beta-cell mitochondria of diabetic rats.

Key words: Pancreatic islets, insulin release, streptozotocin, glucose metabolism, leucine metabolism.
The release of insulin evoked by D-glucose in the pancreatic Beta cell is impaired in adult rats injected with streptozotocin during the neonatal period [1-3]. In this model of non-insulin-dependent diabetes, the impairment of insulin secretion coincides with, and might be attributable to, a decrease in the oxidative response of islet cells to a high concentration of the hexose [3]. This decrease in $\mathrm{D}-\left[\mathrm{U}-{ }^{14} \mathrm{C}\right]$ glucose oxidation and $\mathrm{O}_{2}$ consumption contrasts with a close-to-normal rate of glycolysis [3]. The major aims of the present study are to compare the oxidation of D-glucose and other nutrients in the islets of diabetic and control rats, to further explore the reciprocal coupling between functional and mitochondrial oxidative events in the islets isolated from either control or diabetic animals, and to assess the possible relevance of mitochondrial hexokinase isoenzymes binding to the alteration of the metabolic islet response in diabetic rats.

\section{Materials and methods}

Control rats and animals injected with streptozotocin [4] during the neonatal periods were given free access to food [5] up to the time of killing. The rats were weighed and then decapitated, blood being collected in heparinized tubes. After centrifugation for $10 \mathrm{~min}$ at $1000 \mathrm{~g}$ and $4{ }^{\circ} \mathrm{C}$, the plasma was removed and stored at $-20^{\circ} \mathrm{C}$. The plasma glucose was measured by the glucose oxidase method [6] in $10 \mu \mathrm{l}$ of plasma, and the plasma insulin in $100 \mu \mathrm{l}$ of plasma using a radioimmunoassay described elsewhere [7]. In each experiment, islets were isolated by the collagenase method [8] from the pancreases of three to four rats. Two groups of 15 islets each were sonicated $(3 \times 10 \mathrm{~s})$ in $0.25 \mathrm{ml} \mathrm{H}_{2} \mathrm{O}$ for measurement of islet protein by the method of Lowry et al. [9] using bovine albumin as standard. An aliquot $(25 \mu \mathrm{l})$ of the islet homogenate was mixed with $1.0 \mathrm{ml}$ of a phosphate buffer (100 mmol/l, pH 7.0) containing bovine albumin $(1.0 \%$, weight/volume) and stored at $-20^{\circ} \mathrm{C}$ for measurement of the islet insulin content [8].

For measurement of insulin release, groups of eight islets each were incubated for $120 \mathrm{~min}$ at $37^{\circ} \mathrm{C}$ in $1.0 \mathrm{ml}$ of a bicarbonate-buf- 
Table 1. Metabolic status and islet function

\begin{tabular}{|c|c|c|}
\hline Rats & Control & Diabetic \\
\hline Age (weeks) & $17.0 \pm 0.1 \quad(28)$ & $13.1 \pm 0.4(28)^{\mathrm{a}}$ \\
\hline Body weight (g) & $390 \pm 5$ & $322 \pm 8$ \\
\hline Plasma glucose $(\mathrm{mmol} / \mathrm{l})$ & $7.69 \pm 0.18(26)$ & $9.37 \pm 0.29(25)^{a}$ \\
\hline Plasma insulin ( $\mathrm{mU} / \mathrm{l})$ & $48.7 \pm 6.8(25)$ & $37.5 \pm 5.9(21)$ \\
\hline Islet protein ( $\mu \mathrm{g} /$ islet $)$ & $0.72 \pm 0.07(16)$ & $0.61 \pm 0.05(14)$ \\
\hline Islet insulin (mU/islet) & $1.58 \pm 0.13(16)$ & $0.39 \pm 0.03(16)^{\mathrm{a}}$ \\
\hline \multicolumn{3}{|c|}{ Insulin release $\left(\mu \mathrm{U} \cdot\right.$ islet $\left.^{-1} \cdot 120 \mathrm{~min}^{-1}\right)$} \\
\hline$-\mathrm{Nil}$ & $29.6 \pm 6.5(10)$ & $20.4 \pm 2.1$ \\
\hline - D-glucose $(16.7 \mathrm{mmol} / \mathrm{l}$ & $141.3 \pm 18.3$ & $48.6 \pm 4.8(31)^{\mathrm{a}}$ \\
\hline - L-leucine $(20.0 \mathrm{mmol} / \mathrm{l})$ & $55.5 \pm 5.9(16)$ & $34.0 \pm 2.7(31)^{\mathrm{a}}$ \\
\hline
\end{tabular}

fered medium [8] containing bovine albumin $(5 \mathrm{mg} / \mathrm{ml})$ and equilibrated against a mixture of $\mathrm{O}_{2}(95 \%)$ and $\mathrm{CO}_{2}(5 \%)$. The amount of insulin released in the media was measured as described elsewhere [8].

In all metabolic studies, groups of 15 to 20 islets each were incubated for $120 \mathrm{~min}$ at $37^{\circ} \mathrm{C}$ in $40 \mu$ of the same bicarbonate-buffered medium containing, as required, both D-[5- $\left.{ }^{3} \mathrm{H}\right]$ glucose and D-[6${ }^{14} \mathrm{C}$ ]glucose or only a ${ }^{14} \mathrm{C}$-labelled nutrient. The incubation was halted by addition of $20 \mu \mathrm{l}$ of a citrate-NaOH buffer $(400 \mathrm{mmol} / \mathrm{l}, \mathrm{pH} 4.9)$ containing antimycin A $(0.01 \mathrm{mmol} / 1)$, rotenone $(0.01 \mathrm{mmol} / \mathrm{l})$ and $\mathrm{KCN}(5.0 \mathrm{mmol} / \mathrm{l})$. The oxidation of ${ }^{14} \mathrm{C}$-labelled nutrients was measured as described elsewhere [10], the ${ }^{14} \mathrm{CO}_{2}$ being trapped in hyamine hydroxide over $60 \mathrm{~min}$ incubation at room temperature. When the medium also contained D- $\left[5{ }^{3} \mathrm{H}\right]$ glucose, the recovery of ${ }^{3} \mathrm{H}_{2} \mathrm{O}$ in $0.5 \mathrm{ml}$ of $\mathrm{H}_{2} \mathrm{O}$ was then completed over a further incubation of $22 \mathrm{~h}$ at room temperature [11]. The acidified incubation media containing the islets were then stored at $-20^{\circ} \mathrm{C}$, and later used for measurement of their content in either ${ }^{14} \mathrm{C}$-labelled amino acids, acidic metabolites or lactate. For these measurements, the islets were disrupted by freezing and thawing. The ${ }^{14} \mathrm{C}$-labelled amino acids (e.g. alanine generated from $\left[2-{ }^{14} \mathrm{C}\right]$ pyruvate) and acidic metabolites (e.g. 2-ketoisocaproate generated from $\mathrm{L}-\left[\mathrm{U}-{ }^{1.4} \mathrm{C}\right]$ leucine) were separated from their precursors by chromatography on a Dowex $50 \mathrm{H}^{+}$column, as previously described [12]. For the assay of ${ }^{14} \mathrm{C}$-labelled lactate (generated from D- $\left[6-{ }^{14}\right.$ C]glucose) two aliquots $(40 \mu \mathrm{l}$ each) taken from distinct vials were pooled together, heated for $10 \mathrm{~min}$ at $70^{\circ} \mathrm{C}$, and neutralized by the addition of $15 \mu \mathrm{NaOH}(1.0 \mathrm{~mol} / \mathrm{l})$. Samples ( $40 \mu \mathrm{l}$ each) of the neutralized extract were then mixed with a reaction mixture and incubated with or without lactate dehydrogenase for determination of ${ }^{14} \mathrm{C}$-labelled lactate, as described elsewhere [13].

For measuring the activity of hexokinase and glucokinase, groups of 400 to 600 islets were homogenized in Potter-Elvehjem tubes ( 20 strokes) in $0.3 \mathrm{ml}$ of a Hepes- $\mathrm{NaOH}$ buffer $(10 \mathrm{mmol} / \mathrm{l}$, $\mathrm{pH} 7.0$ ) containing $250 \mathrm{mmol} / \mathrm{l}$ sucrose, $2 \mathrm{mmol} / \mathrm{l}$ EDTA and $2 \mathrm{mmol} / \mathrm{L}$ L-cysteine. After 3 min centrifugation at $1000 \mathrm{~g}$ in order to remove nuclei, cell debris and intact cells, $0.25 \mathrm{ml}$ of the supernatant was again centrifuged for $60 \mathrm{~min}$ at $100,000 \mathrm{~g}$ and $4^{\circ} \mathrm{C}$ [14]. The supernatant of this second centrifugation and the corresponding pellet (resuspended in the same volume of the same buffer) were both sonicated $(3 \times 10 \mathrm{~s})$ and examined for their glucose-phosphorylating activity, which was measured in aliquots of 10 to $30 \mu \mathrm{l}$, over $60 \mathrm{~min}$ incubation at $37^{\circ} \mathrm{C}$ in the presence of $2.0 \mathrm{mmol} / \mathrm{l} \mathrm{ATP}$ and in a final volume of $60 \mu \mathrm{l}$, using a radioisotopic procedure previously described [15].

\section{Statistical analysis}

All results are expressed as the mean $( \pm$ SEM) together with the number of individual determinations $(n)$, each collected in a distinct rat or group of islets, or degree of freedom (d. f.) and statistical significance of differences as assessed by use of Student's $t$-test. The SEM on the sum, difference or ratio between mean values was calculated as indicated elsewhere $[16,17]$.

\section{Results}

\section{Metabolic status and islet function}

The body weight was lower in diabetic than control rats, but the former animals were also younger than the latter ones (Table 1). When examined in the fed state, the plasma glucose concentration was higher in diabetic than control rats, but no significant difference was found in the plasma insulin concentration.

The mean islet protein content was somewhat lower, but not significantly so $(p>0.2)$, in diabetic than control rats, whilst the insulin content of the islets was severely decreased in the diabetic animals.

The basal insulin release, as measured over $120 \mathrm{~min}$ incubation in the absence of exogenous nutrient, was not significantly different $(p>0.05)$ in islets removed from control and diabetic rats, respectively (Table 1 ). In the presence of either D-glucose $(16.7 \mathrm{mmol} / \mathrm{l})$ or L-leucine $(20.0 \mathrm{mmol} / \mathrm{l})$, however, the secretory rate was lower in diabetic than control rats. The hexose-induced increment

Table 2. Oxidation or utilization rate of nutrients by pancreatic islets

\begin{tabular}{|c|c|c|c|c|}
\hline \multirow[t]{2}{*}{ Experiment } & \multirow[t]{2}{*}{ Labelled nutrient (mmol/l) } & \multirow[t]{2}{*}{$\mathrm{Ca}^{2+}(\mathrm{mmol} / \mathrm{l})$} & Control & Diabetic \\
\hline & & & \multicolumn{2}{|l|}{$\left(\mathrm{pmol} \cdot\right.$ islet $\left.^{-1} \cdot 120 \mathrm{~min}^{-1}\right)$} \\
\hline 1 & $\begin{array}{l}\text { D- }\left[6-{ }^{14} \text { C]glucose }(2.8)\right. \\
{\left[2-{ }^{14} \mathrm{C}\right] \text { pyruvate }(1.0)^{\mathrm{e}}} \\
\mathrm{L}-\left[\mathrm{U}-{ }^{14} \mathrm{C}\right] \text { glutamine }(1.0)^{\mathrm{e}} \\
\mathrm{L}-\left[\mathrm{U}-{ }^{14} \mathrm{C}\right] \text { leucine }(1.0)^{\mathrm{e}}\end{array}$ & $\begin{array}{l}1.0 \\
1.0 \\
1.0 \\
1.0\end{array}$ & $\begin{array}{r}4.70 \pm 0.38(15) \\
22.08 \pm 1.64(15) \\
38.23 \pm 1.75(15) \\
14.05 \pm 0.90(15)\end{array}$ & $\begin{array}{c}3.98 \pm 0.34(17) \\
36.86 \pm 2.61(16)^{\mathrm{a}} \\
33.51 \pm 1.88(17)^{\mathrm{b}} \\
18.52 \pm 1.14(17)^{\mathrm{b}}\end{array}$ \\
\hline 2 & $\begin{array}{l}\text { D- }\left[5^{3} \mathrm{H}\right] \text { glucose }(2.8) \\
\text { D- }\left[6^{14} \mathrm{C}\right] \text { glucose }(2.8) \\
\text { D- }\left[5^{3} \mathrm{H}\right] \text { glucose }(16.7) \\
\text { D- }\left[6^{-14} \mathrm{C}\right] \text { glucose }(16.7) \\
\text { D- }\left[5^{3} \mathrm{H}\right] \text { glucose }(16.7) \\
\text { D- }\left[6^{-14} \mathrm{C}\right] \text { glucose }(16.7)\end{array}$ & $\begin{array}{l}1.0 \\
1.0 \\
1.0 \\
1.0 \\
\mathrm{Nil}^{\mathrm{f}} \\
\mathrm{Nil}^{\mathrm{f}}\end{array}$ & $\begin{array}{r}31.53 \pm 2.52(15) \\
4.08 \pm 0.28(15) \\
134.89 \pm 7.72(16) \\
30.94 \pm 1.47(16) \\
117.68 \pm 9.96(15) \\
13.97 \pm 1.07(15)\end{array}$ & $\begin{array}{r}38.01 \pm 2.31(15) \\
4.59 \pm 0.35(15) \\
114.27 \pm 6.02(16)^{\mathrm{d}} \\
18.28 \pm 1.24(16)^{\mathrm{a}} \\
124.56 \pm 6.75(16) \\
13.19 \pm 0.69(16)\end{array}$ \\
\hline 3 & $\begin{array}{l}\text { D- }\left[6^{-14} \mathrm{C}\right] \text { glucose }(16.7) \\
\mathrm{L}-\left[\mathrm{U}-{ }^{14} \mathrm{C}\right] \text { leucine }(20.0) \\
\mathrm{L}-\left[\mathrm{U}-{ }^{14} \mathrm{C}\right] \text { leucine }(20.0)\end{array}$ & $\begin{array}{l}1.0 \\
1.0 \\
\mathrm{Nil}^{\mathrm{f}}\end{array}$ & $\begin{array}{l}34.84 \pm 2.83(28) \\
42.96 \pm 1.89(28) \\
26.59 \pm 1.93(28)\end{array}$ & $\begin{array}{l}21.09 \pm 1.49(25)^{\mathrm{a}} \\
33.06 \pm 2.55(25)^{\mathrm{c}} \\
22.64 \pm 2.08(25)\end{array}$ \\
\hline
\end{tabular}

${ }^{\mathrm{a}} p<0.001 ;{ }^{\mathrm{b}} p<0.01 ;{ }^{\mathrm{c}} p<0.005 ;{ }^{\mathrm{d}} p<0.05$ vs control rats; ${ }^{\mathrm{e}}$ The incubation media also contained $2.8 \mathrm{mmol} / \mathrm{lD}$-glucose; ${ }^{\mathrm{f}}$ The incubation media also contained EGTA $(0.25 \mathrm{mmol} / \mathrm{l})$ and cycloheximide $(0.05 \mathrm{mmol} / \mathrm{l})$ 


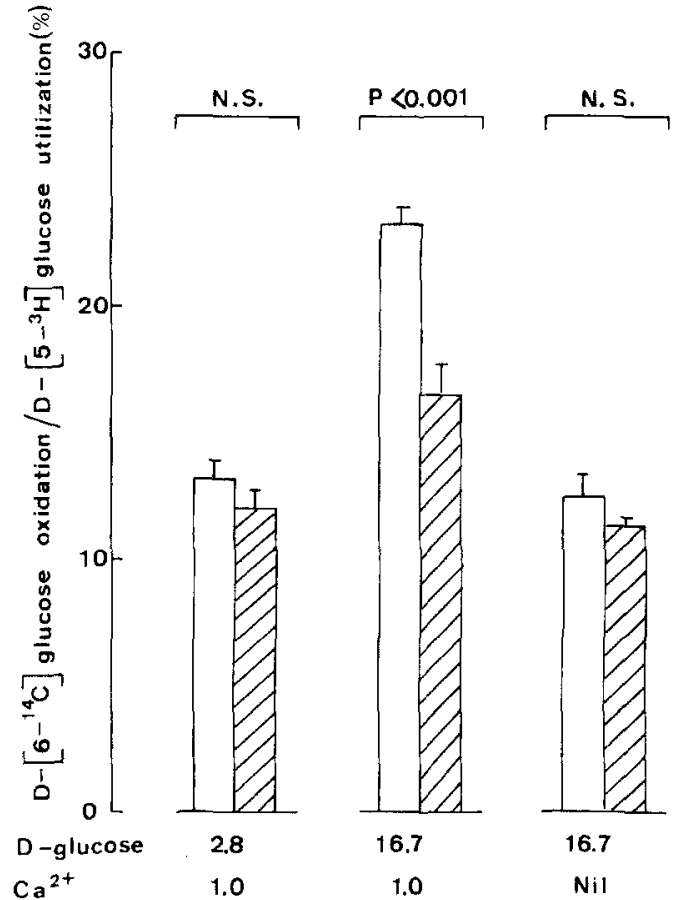

Fig. 1. Ratio of D- $\left[6-{ }^{14} \mathrm{C}\right]$ glucose oxidation to D- $\left[5-{ }^{3} \mathrm{H}\right]$ glucose utilization in islets prepared from control (open columns) and diabetic (hatched columns) rats and incubated in the presence of D-glucose $(2.8$ or $16.7 \mathrm{mmol} / \mathrm{l})$ with or without $\mathrm{Ca}^{2+}$. EGTA $(0.25 \mathrm{mmol} / 1)$ and cycloheximide $(0.05 \mathrm{mmol} / 1)$ were incorporated in the $\mathrm{Ca}^{2+}$-deprived media. Mean values ( \pm SEM) refer to $15-16$ individual measurements, and are shown together with the statistical significance (n.s.: not significant) of differences between control and diabetic rats

in insulin output was four times higher $(p<0.001)$ in control $(111.7 \pm 14.4 \mu \mathrm{U} /$ islet per $120 \mathrm{~min})$ than diabetic rats $(28.2 \pm 5.4 \mu \mathrm{U} / \mathrm{islet}$ per $120 \mathrm{~min})$. The increment in insulin output evoked by L-leucine was not significantly different $(p>0.1)$, however, in control $(25.9 \pm 9.1 \mu \mathrm{U} /$ islet per $120 \mathrm{~min})$ and diabetic rats $(13.6 \pm 3.5 \mu \mathrm{U} /$ islet per $120 \mathrm{~min}$ ). These data suggest that, in the diabetic rats, the secretory response to the amino acid was less severely impaired than that evoked by the hexose.

\section{Isletmetabolism}

When the oxidation of D- $\left[6-{ }^{14} \mathrm{C}\right]$ glucose, $\left[2-{ }^{14} \mathrm{C}\right]$ pyruvate, $\mathrm{L}-\left[\mathrm{U}-{ }^{14} \mathrm{C}\right]$ glutamine or $\mathrm{L}-\left[\mathrm{U}-{ }^{14} \mathrm{C}\right]$ leucine was measured in salt-balanced media and at low, non-insulinotropic, concentrations of these nutrients, no significant impairment of ${ }^{14} \mathrm{CO}_{2}$ production was detected in the diabetic rats (Table 2, Expt. 1). On the contrary, the only significant changes consisted in a modest increase in L- $\left[\mathrm{U}-{ }^{14} \mathrm{C}\right] \mathrm{leu}-$ cine oxidation and a more marked increase in $\left[2-{ }^{14} \mathrm{C}\right]$ pyruvate oxidation. The hierarchy in the oxidation rate of distinct nutrients was not identical in control and diabetic rats. For instance, the ratio between D-glucose and L-leucine oxidation was lower $(p<0.05)$ in diabetic $(22.3 \pm 2.6 \%)$ than control animals $(33.4 \pm 3.4 \%)$.

A different picture was obtained when the metabolism of D-glucose or L-leucine was examined at higher concentrations of these nutrients. In the case of the hexose
(Table 2, Expt. 2), the rate of glycolysis, as judged through the production of ${ }^{3} \mathrm{H}_{2} \mathrm{O}$ from D- $\left[5-{ }^{3} \mathrm{H}\right]$ glucose, was not significantly different in diabetic and control rats at a low concentration of the hexose $(2.8 \mathrm{mmol} / \mathrm{l})$. However, at a higher concentration of D-glucose $(16.7 \mathrm{mmol} / \mathrm{l})$, the rate of glycolysis was slightly lower in diabetic than control animals. Moreover, the $2.8 / 16.7 \mathrm{mmol} / \mathrm{l} \mathrm{ratio}$ in ${ }^{3} \mathrm{H}_{2} \mathrm{O}$ production was significantly higher $(p>0.01)$ in diabetic $(33.8 \pm 2.7 \%)$ than control rats $(23.5 \pm 2.3 \%)$. In other words, the rise in glucose concentration caused a lesser increase of glycolytic rate in diabetic than control rats. Likewise, whereas the rate of $\mathrm{D}-\left[6-{ }^{14} \mathrm{C}\right]$ glucose oxidation was not significantly different in control and diabetic rats at a low concentration of the hexose, it was much lower $(p<0.001)$ in the diabetic than control animals at a high concentration of D-glucose.

The ratio between $\mathrm{D}-\left[6{ }^{-14} \mathrm{C}\right]$ glucose oxidation and $\mathrm{D}-\left[5-{ }^{3} \mathrm{H}\right]$ glucose utilization averaged, in control and diabetic rats respectively, $13.2 \pm 0.7$ and $12.1 \pm 0.7 \%$ in the presence of $2.8 \mathrm{mmol} / \mathrm{l} \mathrm{D}$-glucose and $23.2 \pm 0.7$ and $16.6 \pm 1.2 \%$ in the presence of $16.7 \mathrm{mmol} / \mathrm{l} \mathrm{D}$-glucose (Fig. 1). Thus, the rise in D-glucose concentration caused a preferential stimulation of the oxidation of acetyl residues in the Krebs cycle, relative to the rate of glycolysis, in both control and diabetic rats $(p<0.005)$. However, the relative magnitude of such a preferential stimulation was lower $(p<0.02)$ in diabetic $(+37.1 \pm 12.3 \%)$ than control rats $(+76.0 \pm 10.6 \%)$.

In order to gain further insight into the significance of these metabolic changes, the experiments conducted in the presence of $16.7 \mathrm{mmol} / \mathrm{l} \mathrm{D}$-glucose were repeated in media deprived of $\mathrm{CaCl}_{2}$ and enriched with both EGTA $(0.25 \mathrm{mmol} / \mathrm{l})$ and cycloheximide $(0.05 \mathrm{mmol} / \mathrm{l})$. Under the latter experimental conditions, which aimed at suppressing the functional response of islet cells to $\mathrm{D}$-glucose [11], the rate of $\mathrm{D}-\left[5-{ }^{3} \mathrm{H}\right]$ glucose utilization was not significantly affected, whether in control or diabetic animals. The absence of $\mathrm{Ca}^{2+}$ and presence of cycloheximide significantly decreased $(p<0.005)$, however, the rate of D- $\left[6-{ }^{14} \mathrm{C}\right]$ glucose oxidation, in both control and diabetic rats. The ratio between D- $\left[6-{ }^{14} \mathrm{C}\right]$ glucose oxidation and D- $\left[5-{ }^{3} \mathrm{H}\right]$ glucose utilization was also markedly decreased, in both control and diabetic rats (Fig. 1). Once again, the relative magnitude of the latter change was more pronounced $(p<0.025)$ in control $(-46.2 \pm 4.1 \%)$ than diabetic rats $(-30.4 \pm 5.4 \%)$.

The study of $\mathrm{D}-\left[6-{ }^{14} \mathrm{C}\right]$ glucose catabolism by intact islets also included the measurement of ${ }^{14} \mathrm{C}$-labelled lactate production. Expressed as pmol of glucose residue/islet per $120 \mathrm{~min}$, it averaged, in control and diabetic rats respectively, $16.01 \pm 1.20(n=15)$ and $20.82 \pm 3.07(n=14)$ in the presence of $2.8 \mathrm{mmol} / \mathrm{l} \mathrm{D}$-glucose, $52.86 \pm 5.45(n=18)$ and $47.03 \pm 5.91(n=18)$ in the presence of $16.7 \mathrm{mmol} / 1$ D-glucose, and $43.89 \pm 4.86(n=8)$ and $41.52 \pm 3.59(n=7)$ at the same high concentration of the hexose but in the absence of $\mathrm{Ca}^{2+}$ and presence of EGTA $(0.25 \mathrm{mmol} / \mathrm{l})$ and cycloheximide $(0.05 \mathrm{mmol} / \mathrm{l})$. These data indicate that the production of lactate was not significantly different in control and diabetic rats, whether at a low $(2.8 \mathrm{mmol} / \mathrm{l})$ or high $(16.7 \mathrm{mmol} / \mathrm{l})$ concentration of $\mathrm{D}$-glucose. When measured within the same experiments, the ratio of 
Table 3. Transamination of nutrients in pancreatic islets

\begin{tabular}{|c|c|c|c|c|}
\hline \multirow[t]{2}{*}{ Experiment (as in Table 2) } & \multirow[t]{2}{*}{ Labelled nutrient (mmol/l) } & \multirow[t]{2}{*}{$\mathrm{Ca}^{2+}(\mathrm{mmol} / \mathrm{l})$} & Control & Diabetic \\
\hline & & & \multicolumn{2}{|l|}{$\left(\right.$ pmol islet $\left.{ }^{-1} \cdot 120 \mathrm{~min}^{-1}\right)$} \\
\hline 1 & $\begin{array}{l}{\left[2{ }^{14} \text { Clpyruvate }(1.0)^{b}\right.} \\
\mathrm{L}-\left[\mathrm{U}-{ }^{14} \text { C]leucine }(1.0)^{\mathrm{b}}\right.\end{array}$ & $\begin{array}{l}1.0 \\
1.0\end{array}$ & $\begin{array}{l}17.17 \pm 1.52(15) \\
30.14 \pm 3.29(15)\end{array}$ & $\begin{array}{l}16.92 \pm 1.26(17) \\
45.09 \pm 2.31(17)^{\mathrm{a}}\end{array}$ \\
\hline 3 & $\begin{array}{l}\mathrm{L}-\left[\mathrm{U}-{ }^{14} \mathrm{C}\right] \text { leucine }(20.0) \\
\mathrm{L}-\left[\mathrm{U}-{ }^{14} \mathrm{C}\right] \text { leucine }(20.0)\end{array}$ & $\begin{array}{l}1.0 \\
\text { Nil }^{\mathrm{c}}\end{array}$ & $\begin{array}{r}156.35 \pm 11.88(28) \\
75.52 \pm 7.50(28)\end{array}$ & $\begin{array}{r}142.28 \pm 7.19(25) \\
98.74 \pm 10.96(25)\end{array}$ \\
\hline
\end{tabular}

${ }^{a} p<0.001 ;{ }^{b}$ The incubation media also contained $2.8 \mathrm{mmol} / \mathrm{L}$-glucose; ${ }^{c}$ The incubation media also contained EGTA $(0.25 \mathrm{mmol} / \mathrm{l})$ and cycloheximide $(0.05 \mathrm{mmol} / \mathrm{l})$

Table 4. Hexokinase activity in islet homogenates

\begin{tabular}{|c|c|c|c|c|}
\hline \multirow{2}{*}{$\begin{array}{l}\text { Rats } \\
\text { Subcellular fraction }\end{array}$} & \multicolumn{2}{|l|}{ Control } & \multicolumn{2}{|l|}{ Diabetic } \\
\hline & Cytosol & Mitochondria & Cytosol & Mitochondria \\
\hline \multicolumn{5}{|c|}{ D-glucose phosphorylation rate $\left(\mathrm{pmol} \cdot\right.$ islet $\left.^{-1} \cdot \mathrm{min}^{-1}\right)$} \\
\hline \multicolumn{5}{|c|}{ Glucose 6-phosphate-resistant activity (\%) } \\
\hline - No G6P & $55.2 \pm 1.1$ & $44.8 \pm 1.4$ & $52.3 \pm 2.7$ & $47.7 \pm 2.6$ \\
\hline
\end{tabular}

a Mean values ( \pm SEM) are derived from six individual measurements in all cases

$\left[{ }^{14} \mathrm{C}\right]$ lactate production at $16.7 / 2.8 \mathrm{mmol} / 1 \mathrm{D}$-glucose was significantly lower $(p<0.005)$, however, in diabetic $(2.29 \pm 0.30)$ than control rats $(4.37 \pm 0.58)$, as already observed in the case of $\mathrm{D}-\left[5{ }^{3} \mathrm{H}\right]$ glucose utilization (see above). The absence of $\mathrm{Ca}^{2+}$ and presence of cycloheximide failed to affect significantly the production of $\left[{ }^{14} \mathrm{C}\right]$ lactate, the trend being towards a decreased generation of $\left[{ }^{14} \mathrm{C}\right]$ lactate in both control and diabetic rats.

In both control and diabetic rats, the rate of aerobic glycolysis, taken as the difference between the production of ${ }^{3} \mathrm{H}_{2} \mathrm{O}$ from $\mathrm{D}-\left[5{ }^{3} \mathrm{H}\right]$ glucose and the generation of $\left[{ }^{14} \mathrm{C}\right]$ labelled lactate, increased significantly $(p>0.001)$ in response to a rise in D-glucose concentration from 2.8 to $16.7 \mathrm{mmol} / \mathrm{l}$. Moreover, when expressed relative to the corresponding total glycolytic flux, the fractional contribution of aerobic glycolysis also increased as the concentration of D-glucose was raised from 2.8 to $16.7 \mathrm{mmol} / \mathrm{l}$. The magnitude of such a change was comparable in normal and diabetic rats and, pooling all available data collected in both types of rats, corresponded to an increase in the fractional contribution of aerobic to total glycolysis from $47.2 \pm 5.0 \%$ in the presence of $2.8 \mathrm{mmol} / \mathrm{l} \mathrm{D}$-glucose to $61.3 \pm 3.0 \%$ in the presence of $16.7 \mathrm{mmol} / \mathrm{l} \mathrm{D}$-glucose $(p<0.02)$.

The last experiments in this series aimed at comparing the oxidation of D- $\left[6-{ }^{14} \mathrm{C}\right]$ glucose and $\mathrm{L}-\left[\mathrm{U}-{ }^{14} \mathrm{C}\right]$ leucine (Table 2, Expt. 3). The oxidation of $\mathrm{L}-\left[\mathrm{U}_{-}{ }^{14} \mathrm{C}\right]$ leucine, at a high concentration of the amino acid $(20.0 \mathrm{mmol} / \mathrm{l})$ and in salt-balanced media, was lower in diabetic than control rats. When measured within the same experiments, the oxidation rate of D- $\left[6-{ }^{14} \mathrm{C}\right]$ glucose $(16.7 \mathrm{mmol} / \mathrm{l})$ relative to that of $\mathrm{L}-\left[\mathrm{U}-{ }^{14} \mathrm{C}\right]$ leucine $(20.0 \mathrm{mmol} / \mathrm{l})$ averaged $81.1 \pm 6.6 \%(n=28)$ in control rats, as distinct $(p<0.05)$ from only $63.8 \pm 4.5 \%(n=25)$ in diabetic rats. This indicates a more severe alteration of the mitochondrial oxida- tion of the hexose rather than amino acid, as a result of the neonatal administration of streptozotocin.

Moreover, in the absence of $\mathrm{CaCl}_{2}$ but presence of EGTA $(0.25 \mathrm{mmol} / \mathrm{l})$ and cycloheximide $(0.05 \mathrm{mmol} / \mathrm{l})$, the oxidation of L- $\left[\mathrm{U}-{ }^{14} \mathrm{C}\right]$ leucine $(20.0 \mathrm{mmol} / \mathrm{l})$ was decreased $(p<0.005)$ to $61.9 \pm 6.3 \% \quad($ d.f. $=54)$ and $68.5 \pm 9.9 \%$ (d.f. $=48)$ of its corresponding control value in normal and diabetic rats, respectively. The latter two percentages were not significantly different from one another $(p>0.5)$, in sharp contrast to the situation found with $\mathrm{D}-\left[6-{ }^{14} \mathrm{C}\right]$ glucose $(16.7 \mathrm{mmol} / \mathrm{l})$. This indicates that, in terms of the interdependency between oxidative and functional responses, the situation in diabetic animals was again more severely perturbed in glucose- than leucinestimulated islets.

The operation of transamination reactions in intact islets was also investigated by measuring the generation of ${ }^{14} \mathrm{C}$-labelled amino acids in islets exposed to $\left[2{ }^{14} \mathrm{C}\right]$ pyruvate and that of ${ }^{14} \mathrm{C}$-labelled acidic metabolites in islets exposed to L-[U- $\left.{ }^{14} \mathrm{C}\right]$ leucine (Table 3 ). The generation of ${ }^{14} \mathrm{C}$-labelled amino acids, presumably mainly $[2-$ $\left.{ }^{14} \mathrm{C}\right]$ alanine, by islets exposed to $\left[2-{ }^{14} \mathrm{C}\right]$ pyruvate was not significantly different in normal and diabetic rats. The generation of ${ }^{14} \mathrm{C}$-labelled acidic metabolites, mainly [U$\left.{ }^{14} \mathrm{C}\right] 2$-ketoisocaproate [18], by islets exposed to $\mathrm{L}$-[U$\left.{ }^{14} \mathrm{C}\right]$ leucine was higher $(p<0.001)$ in diabetic than control rats, when the amino acid was tested at a low concentration $(1.0 \mathrm{mmol} / \mathrm{l})$. Such a difference was no longer observed, however, when L-leucine was tested at a concentration of $20.0 \mathrm{mmol} / \mathrm{l}$. In the latter case, the absence of $\mathrm{Ca}^{2+}$ and presence of cycloheximide decreased $(p<0.005)$ the generation of ${ }^{14} \mathrm{C}$-labelled acidic metabolites in both control and diabetic rats. The relative extent of such an inhibition was somewhat less marked, albeit not significantly so, in diabetic rats $(-30.6 \pm 9.0 \%$; d.f. $=48)$ than con- 


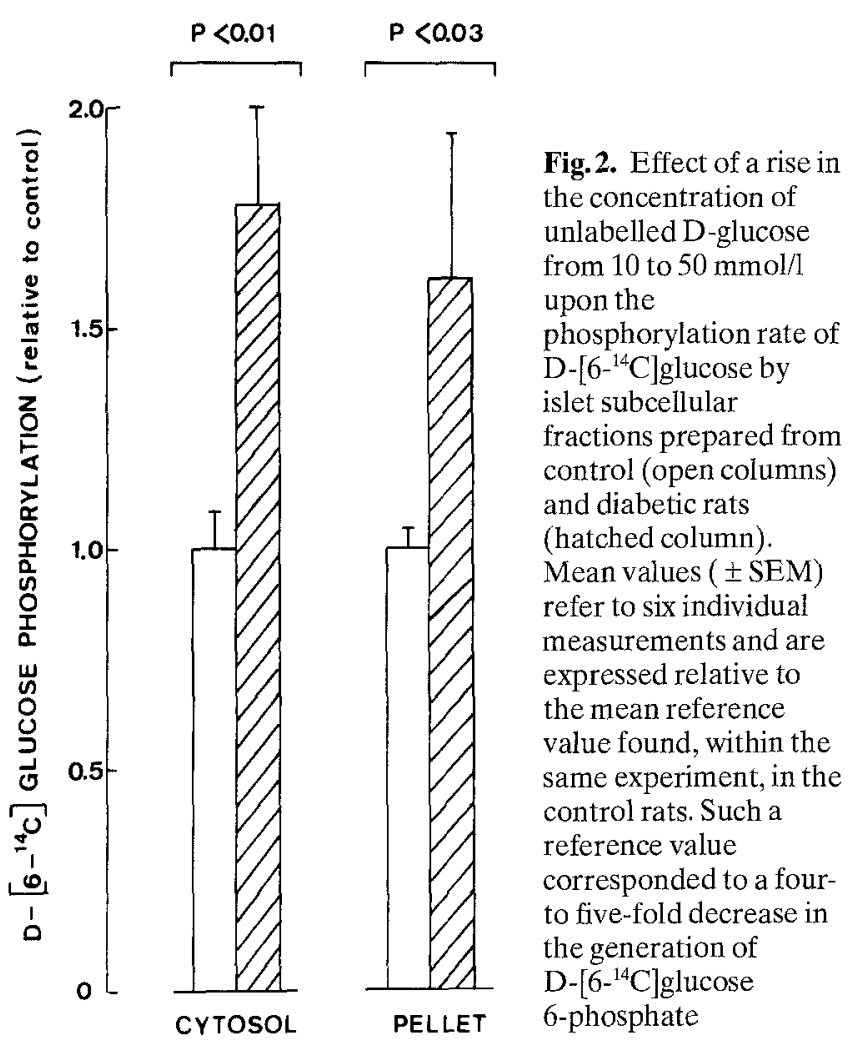

trol animals $(-51.7 \pm 9.0 \%$; d.f. $=54)$. In both control and diabetic rats, the oxidation of $\mathrm{L}-\left[\mathrm{U}-{ }^{14} \mathrm{C}\right]$ leucine relative to the generation of $\left[\mathrm{U}-{ }^{14} \mathrm{C}\right] 2$-ketoisocaproate and other ${ }^{14} \mathrm{C}$ labelled acidic metabolites was higher in the presence of $1.0 \mathrm{mmol} / \mathrm{l}$ rather than $20.0 \mathrm{mmol} / \mathrm{l}$ L-leucine. Thus, such a relative oxidation rate decreased, in response to the rise in L-leucine concentration, from $46.6 \pm 5.9$ to $27.5 \pm 2.4 \%$ in control rats and from $41.1 \pm 3.3$ to $23.2 \pm 2.1 \%$ in diabetic rats $(p<0.005)$.

\section{D-glucose phosphorylation by islet homogenates}

Because of the preferential perturbation of D-glucose catabolism in the islets of diabetic rats and in view of the essential role currently ascribed to D-glucose phosphorylation in the regulation of hexose metabolism in islet cells, the activity of hexokinase and glucokinase in islet homogenates was examined in the last part of the present study. Moreover, because of the potential regulatory role of hexokinase isoenzymes binding to mitochondria, the enzymatic data were collected in both a particulate and soluble subcellular fractions prepared from the islet crude homogenates.

The total activity of hexokinase, as measured in the presence of $0.6 \mathrm{mmol} / 1 \mathrm{D}$-glucose, was higher in diabetic than control rats, averaging respectively $6.08 \pm 0.44$ and $4.47 \pm 0.05 \mathrm{pmol} /$ islet per $\mathrm{min}(p<0.005)$. The relative contribution of cytosolic and mitochondrial material to the total rate of hexose phosphorylation was not significantly different in control and diabetic rats (Table 4). Dglucose 6-phosphate (initial concentration: $3.0 \mathrm{mmol} / \mathrm{l}$ ) severely inhibited hexokinase activity. In both control and diabetic rats, the relative extent of such an inhibition was higher $(p<0.001)$ in the cytosolic than mitochondrial material, as expected from prior observations $[14,19]$.

The total activity of glucokinase, as judged from the paired difference in the phosphorylation rate of D-glucose tested at concentrations of $0.6 \mathrm{mmol} / \mathrm{l}$ and $10.0 \mathrm{mmol} / \mathrm{l}$ respectively, was not significantly different $(p>0.2)$ in control $(1.39 \pm 0.16 \mathrm{pmol} /$ islet per min) and diabetic rats ( $1.65 \pm 0.13 \mathrm{pmol} /$ islet per min). It accounted, in control and diabetic animals respectively, for $23.9 \pm 2.7 \%$ and $21.8 \pm 1.6 \%$ of the total rate of hexose phosphorylation recorded in the presence of $10.0 \mathrm{mmol} / \mathrm{l}$ D-glucose (Table 5). The fractional contributions of the soluble and particulate-bound glucokinase were similar in control and diabetic rats, accounting each for about half of the total enzymatic activity.

In the study of glucokinase activity, the sole difference between control and diabetic rats was observed when the concentration of unlabelled D-glucose was raised from 10 to $50 \mathrm{mmol} / \mathrm{l}$, whilst keeping the concentration of $\mathrm{D}$ - $[6$ ${ }^{14} \mathrm{C}$ glucose unchanged. The decrease in the generation rate of D-[6- $\left.{ }^{14} \mathrm{C}\right]$ glucose 6-phosphate resulting from such an increase in the concentration of unlabelled D-glucose was indeed less marked in diabetic than control rats (Fig. 2). This difference was observed in both the cytosolic and mitochondrial fraction.

\section{Discussion}

The present study extends prior investigations on the metabolic and functional anomalies in islets prepared from adult rats which were injected with streptozotocin during

Table 5. Glucokinase activity in islet homogenates

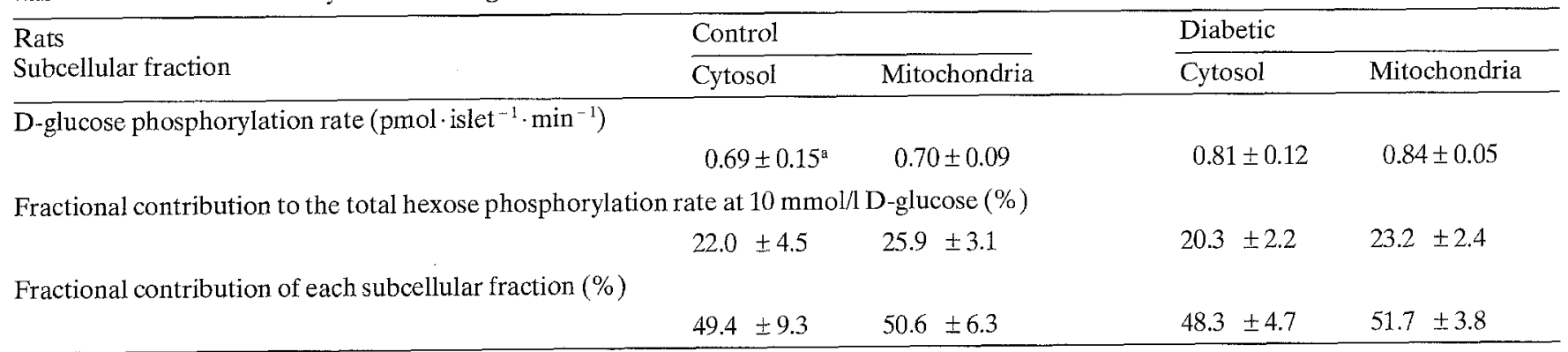

a Mean values ( \pm SEM) are derived from six individual measurements in all cases 
the neonatal period $[2,3]$. These anomalies may result from a long-lasting effect of streptozotocin [19] and/or mild hyperglycaemia.

Our results suggest that the capacity of mitochondria to oxidize D-glucose, pyruvate, L-glutamine and L-leucine is not impaired in the diabetic rats, at least when these nutrients are tested at non-insulinotropic concentrations and even more so that the size of the islets might be somewhat lower in diabetic than control rats.

Likewise, the transamination data collected in intact islets indicate that there is no alteration of the latter process in diabetic rats. Since the generation of 2-ketoisocaproate from L-leucine, in the islets, is critically dependent on the activation of glutamate dehydrogenase by the amino acid [20], these data also suggest that there is no obvious perturbation in the activity of the latter mitochondrial enzyme. Nevertheless, the fact that, in the presence of $20.0 \mathrm{mmol} / \mathrm{l} \mathrm{L}$-leucine, the oxidation of the amino acid was lower in diabetic than control rats points to an alteration in the oxidative catabolism of 2-ketoisocaproate, generated from exogenous L-leucine, as a possible cause of the impaired secretory response to L-leucine recorded in the islets from diabetic rats. The latter secretory defect sharply contrasts with the increased responsiveness to L-leucine recorded in the perfused pancreas of diabetic rats [1]. The factors responsible for such contrasting behaviour of the Beta cell in the perfused pancreas and isolated islets, respectively, remain to be identified.

Three converging series of observations indicated that the metabolic and secretory response of islet cells was more severely perturbed in the case of D-glucose than L-leucine. First, as judged from the increment in insulin release evoked by these nutrients, the response to D-glucose was more markedly affected than that to L-leucine. Second, a preferential alteration of D-glucose catabolism was documented by the direct comparison of D-[6$\left.{ }^{14} \mathrm{C}\right]$ glucose and L-[U- $\left.{ }^{14} \mathrm{C}\right]$ leucine oxidation in both control and diabetic rats. In this respect, comparable results were obtained at low and high concentrations of these nutrient secretagogues. Third, the reciprocal coupling between oxidative and functional events, as judged from the changes evoked by the absence of $\mathrm{Ca}^{2+}$ and presence of cycloheximide [11], also indicated a severe alteration in the case of glucose-stimulated islets prepared from diabetic rats, whereas no significant difference between normal and diabetic rats was recorded when the same environmental factors were tested in leucine-stimulated islets.

The present results suggest that the preferential alteration of the Beta cell response to D-glucose in this model of non-insulin-dependent diabetes is not attributable to either a decrease in hexokinase and glucokinase activities or an altered binding of these isoenzymes to mitochondria. In the case of the high $\mathrm{K}_{\mathrm{m}}$ glucokinase, the sole perturbation in the diabetic animals resided in an apparently decreased affinity for $\mathrm{D}$-glucose. The same change in the kinetic behaviour of glucokinase was recently observed in the liver of streptozotocin-induced diabetic adult rats [21]. This anomaly might possibly account, in part at least, for the lesser increase in glycolytic flux observed in the islets of diabetic rather than control rats in response to a rise in extracellular D-glucose concentration from 2.8 to $16.7 \mathrm{mmol} / \mathrm{l}$.

The absolute rate of glycolysis at the high concentration of D-glucose was little affected, however, in the islets of diabetic rats. The major metabolic anomaly in glucosestimulated islets from diabetic rats consisted in an impaired preferential stimulation of D- $\left[6-{ }^{14} \mathrm{C}\right]$ glucose oxidation. This mitochondrial defect coincided with a lesser sensitivity towards the absence of $\mathrm{Ca}^{2+}$ and presence of cycloheximide of the same biochemical process, i.e. the oxidation of acetyl residues in the Krebs cycle in islets exposed to a high concentration of extracellular D-glucose. Recent observations ascribe a key role to the mitochondrial accumulation of calcium and subsequent activation of calcium-dependent mitochondrial dehydrogenases (e.g. glycerol phosphate dehydrogenase and 2-ketoglutarate dehydrogenase) in the preferential stimulation by D-glucose of mitochondrial oxidative events (such as circulation in the glycerol phosphate shuttle and acetyl residues oxidation in the Krebs cycle) in the islet cells [22, 23]. It is conceivable, therefore, that the altered response of pancreatic islets to either a rise in D-glucose concentration or the removal of $\mathrm{Ca}^{2+}$, as judged from the ratio between D- $\left[6-{ }^{14} \mathrm{C}\right]$ glucose oxidation and D- $\left[5-{ }^{3} \mathrm{H}\right]$ glucose utilization, is mainly attributable to an alteration, at the mitochondrial level, of this reciprocal coupling between cationic and oxidative events.

In conclusion, although the perturbation of the Betacell secretory behaviour in the present model of non-insulin-dependent diabetes might be attributable to several distinct metabolic defects, our results point, nevertheless, towards an alteration in the interdependency of $\mathrm{Ca}^{2+}$ handling and mitochondrial oxidative events as a major determinant of the preferential impairment of the Betacell responsiveness to D-glucose. In this respect, the present findings emphasize the view [24] that the transport of D-glucose across the plasma membrane and its subsequent phosphorylation by glucokinase should not be considered as the sole, possibly even not the major, regulatory factors of the functional response to D-glucose, whether in normal or diseased Beta cells.

Acknowledgements. The authors are most grateful to J. Schoonheydt and M. Urbain for technical assistance and C. Demesmaeker for secretarial help. This work was supported by grants from the Institut National de la Santé et de la Recherche Médicale (France), Foundation for Scientific Medical Research (Belgium) and Ministry of Scientific Policy (Belgium).

\section{References}

1. Giroix M-H, Portha B, Kergoat M, Bailbe D, Picon L (1983) Glucose insensitivity and aminoacid hypersensitivity of insulin release in rats with non-insulin-dependent diabetes: a study with the perfused pancreas. Diabetes 32: 445-451

2. Portha B (1985) Decreased glucose-induced insulin release and biosynthesis by islets of rats with non-insulin-dependent diabetes: effect of tissue culture. Endocrinology 117: 1735-1741

3. Portha B, Giroix M-H, Serradas P, Welsh N, Hellerström C, Sener A, Malaisse WJ (1988) Insulin production and glucose metabolism in isolated pancreatic islets of rats with non-insulin-dependent diabetes. Diabetes 37: 1226-1233 
4. Portha B, Levacher C, Picon L, Rosselin G (1974) Diabetogenic effect of streptozotocin in the rat during the perinatal period. Diabetes 23: 889-895

5. Portha B, Picon L, Rosselin G (1979) Chemical diabetes in the adult rat as the spontaneous evolution of neonatal diabetes. Diabetologia 17: 371-377

6. Bergmeyer HU, Bernt E (1974) D-glucose determination with glucose oxidase and peroxidase. In: Bergmeyer $\mathrm{HU}$ (ed) Methods of Enzymatic Analysis. Academic, New York, pp 12051215

7. Leclercq-Meyer V, Marchand J, Woussen-Colle MC, Giroix M-H, Malaisse WJ (1985) Multiple effects of leucine on glucagon, insulin, and somatostatin secretion from the perfused rat pancreas. Endocrinology 116: 1168-1174

8. Malaisse-Lagae F, Malaisse WJ (1984) Insulin release by pancreatic islets. In: Larner J, Pohl SL (eds) Methods in diabetes research. Wiley and Sons, New York, pp 147-152

9. Lowry OH, Rosebrough NJ, Farr AL, Randall RJ (1951) Protein measurement with the folin phenol reagent. J Biol Chem 193: 265-275

10. Carpinelli AR, Sener A, Herchuelz A, Malaisse WJ (1980) The stimulus-secretion coupling of glucose-induced insulin release. XLI. Effect of intracellular acidification upon calcium efflux from islet cells. Metabolism 29:540-545

11. Malaisse WJ, Sener A (1988) Hexose metabolism in pancreatic islets. Feedback control of D-glucose oxidation by functional events. Biochim Biophys Acta 971:246-254

12. Malaisse WJ, Sener A, Malaisse-Lagae F, Hutton JC, Christophe J (1981) The stimulus-secretion coupling of amino acid-induced insulin release. VI. Metabolic interaction of L-glutamine and 2-ketoisocaproate in pancreatic islets. Biochim Biophys Acta 677:39-49

13. Sener A, Malaisse-Lagae F, Malaisse WJ (1987) Fructose metabolism via the pentose cycle in tumoral islet cells. Eur J Biochem 170: $447-452$

14. Sener A, Malaisse-Lagae F, Giroix M-H, Malaisse WJ (1986) Hexose metabolism in pancreatic islets: compartmentation of hexokinase in islet cells. Arch Biochem Biophys 251:61-67

15. Giroix M-H, Sener A, Pipeleers DG, Malaisse WJ (1984) Hexose metabolism in pancreatic islets. Inhibition of hexokinase. Biochem J 223: 447-453
16. Malaisse WJ, Sener A, Carpinelli AR, Anjaneyulu K, Lebrun P, Herchuelz A, Christophe $\mathcal{J}$ (1980) The stimulus-secretion coupling of glucose-induced insulin release. XLVI. Physiological role of $\mathrm{L}$-glutamine as a fuel for pancreatic islets. Mol Cell Endocrinol 20: 171-189

17. Sener A, Malaisse-Lagae F, Dufrane SP, Malaisse WJ (1984) The coupling of metabolic to secretory events in pancreatic islets. The cytosolic redox state. Biochem J 220: 433-440

18. Malaisse WJ, Hutton JC, Carpinelli AR, Herchuelz A, Sener A (1980) The stimulus-secretion coupling of amino acid-induced insulin release. I. Metabolism and cationic effects of L-leucine. Diabetes 29: 431-437

19. Eizirik DL, Sandler S, Sener A, Malaisse WJ (1988) Defective catabolism of D-glucose and L-glutamine in mouse pancreatic islets maintained in culture after streptozotocin exposure. Endocrinology 123: 1001-1007

20. Sener A, Malaisse-Lagae F, Malaisse WJ (1983) Does leucine and norleucine-induced insulin release depend on amino acid aminotransferase activity? J Biol Chem 258: 6693-6694

21. Zähner D, Malaisse WJ (1989) Altered kinetic behaviour of liver glucokinase in streptozotocin-diabetic rats. Diabetes 38 [Suppl 2]: 104A (Abstract)

22. Sener A, Malaisse WJ (1987) Stimulation by D-glucose of mitochondrial oxidative events in islet cells. Biochem J 246: 89-95

23. Malaisse WJ, Rasschaert J, Sener A (1990) Activation of the 2-ketoglutarate dehydrogenase complex in glucose-stimulated pancreatic islets. Diabetes 39 [Suppl 1]: 66A

24. Malaisse WJ (1988) Insulin release: physiology and pathophysiology of nutrient metabolism in pancreatic islets. In: Grill V (ed) Pathogenesis of non-insulin dependent diabetes mellitus. Raven, New York, pp 27-38

Received: 23 January 1990

and in revised form: 17 July 1990

Prof. Dr. W. J. Malaisse

Laboratory of Experimental Medicine

Brussels Free University

115 Boulevard de Waterloo

B-1000 Brussels

Belgium 